\title{
Female Soccer Players' Psychological Profile: Differences between Professional and Amateur Players
}

\author{
Cecilia Ruiz-Esteban ${ }^{1}$, Aurelio Olmedilla ${ }^{2, *}$ (D) Inmaculada Méndez ${ }^{1, * \mathbb{C}}$ and Juan Jesús Tobal ${ }^{1}$ \\ 1 Department of Evolutionary Developmental and Educational Psychology, Campus Regional Excellence Mare \\ Nostrum, University of Murcia, 30100 Murcia, Spain; cruiz@um.es (C.R.-E.); juanje.tobal@gmail.com (J.J.T.) \\ 2 Department of Personality, Assessment and Psychological Treatment, Campus Regional Excellence Mare \\ Nostrum, University of Murcia, 30100 Murcia, Spain \\ * Correspondence: olmedilla@um.es (A.O.); inmamendez@um.es (I.M.); Tel.: +34-868-883-463 (A.O.); \\ +34-868-884-575 (I.M.)
}

Received: 26 May 2020; Accepted: 16 June 2020; Published: 18 June 2020

\begin{abstract}
The psychological variables that affect competitive performance are called the psychological profile of athletes. In recent years, the interest in female soccer players and the psychological characteristics that affect their performance has increased. The aim of the present study is to analyze the psychological characteristics of female professional soccer players and female amateur soccer players, as well as to determine the differences in the psychological profile of both groups. The participants were 134 federated female soccer players, with an average age of 18.28 years $(\mathrm{SD}=4.05)$. To assess the psychological profile, the questionnaire on Psychological Characteristics related to Sports Performance (CPRD) by Gimeno, Buceta, and Pérez-Llantada (2001) was used. The results showed that female professional players presented higher values for motivation, while the female amateur players presented higher values for stress control and the influence of performance evaluation. These results can have a great impact on coaches' work, since they can help them to establish tasks and training methods consistent with the characteristics of their players.
\end{abstract}

Keywords: CPRD; psychological variables; psychological profile; female soccer; competitive performance

\section{Introduction}

During the last few decades, there has been a significant increase in the study of psychological characteristics related to sports performance [1]. The psychological variables that affect competitive performance are called the psychological profile of athletes [2,3]. This profile might be useful in training processes and can improve performances in competitions $[4,5]$ due to the mediation that these psychological variables achieve between the physical, technical, and tactical abilities of the athlete and his/her performance [6,7]. Several authors have pointed out that attention control, self-confidence, coping strategies, and motivation are some of those variables [8,9]. Urra [10] found that training coping strategies were able to reduce precompetitive anxiety and improve performance during a competition. According to Días, Cruz, and Fonseca [11], self-confidence is a predictor of success in competitions.

Several investigations have shown that there is no single athlete profile. Instead, these profiles depend on other variables, such as the type of sport, gender of the athlete, and competitive level [12]. Some authors have studied the psychological profiles of athletes based on their competitive level. For example, Riddick [13] conducted a study on professional and amateur swimmers, indicating that amateurs manifest more positive personality traits than professional swimmers. More recently, López-Gullón et al. [9] pointed out the differences between amateur and professional athletes in 
Olympic and Greco-Roman wrestling, with self-confidence and attitudinal control differentiating them. Saber et al. [14] found differences in the profiles of expert and nonexpert taekwondo players. The studies by Vaca et al. [15] showed different levels of precompetitive anxiety in amateur, novice, and high-level karate competitors. In the field of soccer, Pestillo de Oliveira et al. [16] observed that professional players demonstrated more confidence and motivation to overcome the obstacles of the sports context than nonprofessional players. Other studies have highlighted gender differences in the psychological profiles of some athletes. Females showed higher levels of neuroticism, awareness, and kindness than males [17], as well as depression and anxiety [18]. Arias, Cardoso, Aguirre, and Arenas [19] have pointed out that while in female soccer, better values for team cohesion were registered, in volleyball, females scored higher in terms of motivation and mental ability. However, males have obtained higher values than females in aspects such as sports identification [20], self-esteem, ego, autonomy and enjoyment [21], and motivation [22]. Saber et al. [14] found different psychological profiles for male and female taekwondo players, and Alvarez et al. [23] found motivation and self-confidence as variables that change in the profiles, depending on gender. However, few studies have focused exclusively on the psychological profile of female athletes.

Soccer has been one of the sports more extensively studied in recent years in terms of the psychological profile of players, maybe due to the importance of these psychological variables in football training [12]. More recently, and due to a social change regarding the gender perspective, the interest in female soccer and the psychological characteristics that affect their performance has increased. Williams [24] has pointed out that the mental toughness, self-esteem, and anxiety control of female players are fundamental psychological traits for success. Arroyo del Bosque, Irazusta, and González-Rodríguez [25] focused on states of mood (tension, hostility, depression, vigor, and fatigue) of female soccer players. However, although there are other very interesting studies on female soccer [26,27], no studies have been found that compare the psychological profiles of amateur soccer players and those who are professionals. By knowing the psychological characteristics of professional players, the work of coaches and sports technicians, at all competition levels, could improve. Therefore, assessing the psychological capacities is a first step towards correct psychological training aimed at improving the performance of players, both professional and young, in training [28,29].

Therefore, the aim of this study was to analyze the psychological characteristics (stress control, influence of performance evaluation, motivation, and mental ability) of female professional soccer players and amateur soccer players, as well as to determine differences in the psychological profile of both groups.

The hypotheses of this study were as follows:

- Stress control will be higher in female professional soccer players than in amateur players;

- The influence of performance evaluation will be greater in female professional soccer players than in amateur players;

- Motivation will be higher in female professional soccer players than in amateur players;

- Mental ability will be higher in female professional soccer players than in amateur players;

- Team cohesion will be greater in female professional players than in amateur players.

\section{Materials and Methods}

\subsection{Participants}

A descriptive cross-sectional design was used. The participants were 134 female Spanish soccer players with a mean age of 18.28 years $(\mathrm{SD}=4.05)$. Of these, $30.6 \%$ were professionals and the remaining $69.4 \%$ were amateurs. It was a nonprobability sample collected from the Soccer Association of the Region of Murcia (FFRM). The inclusion criteria were (a) being federated, (b) being a woman, (c) enrolling in a competition for at least three years, and (d) being older than 14 years. The only exclusion criterion was being injured. Of the 139 players who met the inclusion criteria, five were dismissed when applying the exclusion criteria. A professional player was defined as one who had a 
signed contract meaning that the player received financial compensation. All females who played in the second division and six females of the first division were considered as professionals $(\mathrm{N}=41)$. The remaining players were listed as amateurs. Only $6.7 \%$ of the female players had competed in other sports; of these, $2.98 \%$ were professionals. Participation in the study was voluntary after the researchers reported on the study objectives.

\subsection{Instruments}

Psychological variables were assessed using the Psychological Characteristics Related to Sport Performance Questionnaire (CPRD) [30] (see Table 1), based on the Psychological Skills Inventory for Sports (PSIS) [31]. The questionnaire consists of 55 items graded in a four-option Likert scale (from totally disagree to totally agree).

Table 1. Sociodemographic data of professionals and amateurs.

\begin{tabular}{lcccccc}
\hline Educative Level & $\mathbf{N}$ & $\begin{array}{c}\text { Totals } \\
\text { Percentage (\%) }\end{array}$ & $\mathbf{N}$ & $\begin{array}{c}\text { Professional } \\
\text { Percentage (\%) }\end{array}$ & N & $\begin{array}{c}\text { Amateurs } \\
\text { Percentage (\%) }\end{array}$ \\
\hline Compulsory Secondary Education & 72 & 53.7 & 13 & 9.7 & 59 & 44.0 \\
Bachelor & 55 & 41.0 & 26 & 19.4 & 29 & 21.6 \\
Vocational Education & 7 & 5.2 & 2 & 1.5 & 5 & 3.8 \\
Total & 134 & 100 & 41 & 30.6 & 93 & 69.4 \\
\hline Soccer Player Position & $\mathbf{N}$ & Percentage (\%) & $\mathbf{N}$ & Percentage (\%) & $\mathbf{N}$ & Percentage (\%) \\
\hline Goalkeeper & 15 & 11.2 & 2 & 1.49 & 13 & 9.7 \\
Defender & 45 & 33.6 & 10 & 7.46 & 35 & 26.1 \\
Midfielder & 42 & 31.2 & 17 & 12.6 & 25 & 18.6 \\
Forward & 32 & 23.9 & 12 & 8.9 & 20 & 14.9 \\
Total & 134 & 100 & 41 & 30.6 & 93 & 69.4 \\
\hline Maximum Division Played & $\mathbf{N}$ & Percentage (\%) & $\mathbf{N}$ & Percentage (\%) & $\mathbf{N}$ & Percentage (\%) \\
\hline Second division league & 35 & 26.1 & 35 & 26.1 & 0 & 0 \\
Third division league & 83 & 61.9 & 0 & 0 & 83 & 61.9 \\
First division league & 6 & 4.5 & 6 & 4.5 & 0 & 0 \\
Regional league & 8 & 6.0 & 0 & 0 & 8 & 6.0 \\
Local league & 2 & 1.5 & 0 & 0 & 2 & 1.5 \\
Total & 134 & 100 & 41 & 30.6 & 93 & 69.4 \\
\hline Soccer Federation Years & $\mathbf{N}$ & Percentage (\%) & $\mathbf{N}$ & Percentage (\%) & $\mathbf{N}$ & Percentage (\%) \\
\hline <4 years & 43 & 32.0 & 9 & 6.7 & 34 & 25.3 \\
From 4 to 9 years & 51 & 38.2 & 19 & 14.2 & 32 & 24 \\
$>9$ years & 40 & 29.8 & 13 & 9.7 & 27 & 20.1 \\
Total & 134 & 100 & 41 & 30.6 & 93 & 69.4 \\
\hline
\end{tabular}

CPRD includes five subscales: Stress control (SC), influence of performance evaluation (IPE), motivation (M), mental skills (MS), and team cohesion (TC). Cronbach's alpha coefficient for the subscales is $\alpha_{\mathrm{SC}}=0.88, \alpha_{\mathrm{IPE}}=0.72, \alpha_{\mathrm{M}}=0.67, \alpha_{\mathrm{TCOH}}=0.78$ and $\alpha_{\mathrm{MSK}}=0.34$, respectively. According to the authors, the low internal consistency of MS is probably related to this dimension including a wide range of different skills, but the subscale was kept within the study due to the factorials loads displayed by the items of this factor (over 0.30) [32].

Sociodemographic variables were assessed using an ad hoc questionnaire inserted at the beginning of the CPRD. The information collected is shown in Table 1.

\subsection{Procedure}

A list of females was requested from the Murcia Region Football Federation (FFRM). Subjects who met the sampling requirements for convenience were recruited. Later, an appointment was arranged with the coach, players, and their parents if they were minors. Finally, those players who 
agreed to participate in the research signed an informed consent form, and in the case of minors, their parents/guardians signed it. Tests were applied individually.

\subsection{Data Analysis}

First, a percentage analysis of the sociodemographic variables by both groups, professionals and amateurs, was carried out. Then, a descriptive analysis of each of the psychological variables (mean and standard deviation) was performed. Subsequently, a discriminant analysis [33] was conducted. Standardized coefficients greater than or equal to 0.30 [34] were considered relevant for the interpretation of the linear vectors. To ascertain the differences in each of the psychological variables independently, a Student's $t$-test was used for independent samples.

The professionals and amateurs were compared by the method of magnitude-based inferences (MBI) (standardized Cohen's d values and their 90\% confidence intervals). The comparison of each psychological measure was done using Hopkins' spreadsheet with the smallest worthwhile difference [35]. This method calculated 0.2 times the standardization, estimated from the between-subjects standard deviation. The magnitude of a clear difference was assessed as follows: $>0.25 \%$, trivial; $0.25 \%-75 \%$, possibly; $75 \%-95 \%$, likely; $95 \%-99 \%$, very likely; $>99 \%$, most likely [36].

Statistical analysis was carried out through the statistical program IBM SPSS Statistics 23.0 (IBM Corp., Armonk, NY, USA), establishing the value of statistical significance at $p<0.05$.

\subsection{Ethical Approval}

The study obtained the approval of the Ethical Committee of the University of Murcia (ID 2303/2019). This study was performed in accordance with the approved guidelines and the Declaration of Helsinki and with the informed consent of the participants.

\section{Results}

Several sociodemographic variables, such as educational level, player position, maximum division played, and federation years, have been analyzed (see Table 1).

Table 2 shows the means and standard deviation of the different psychological variables under study in female professional and amateur soccer players.

Table 2. Scores of the psychological variables under study (mean, standard deviation, and significance level) of female professional and amateur soccer players.

\begin{tabular}{ccccc}
\hline Psychological Factors & Professional & Amateur & $p$ & $\mathbf{d}$ \\
\hline Stress control & $27.22 \pm 11.54$ & $34.32 \pm 12.36$ & 0.002 & 0.59 \\
Influence of performance evaluation & $18.27 \pm 6.13$ & $20.28 \pm 6.72$ & 0.050 & 0.31 \\
Motivation & $13.39 \pm 5.04$ & $11.85 \pm 3.24$ & 0.036 & 0.36 \\
Mental skills & $15.29 \pm 4.47$ & $14.24 \pm 3.36$ & 0.134 & 0.26 \\
Team cohesion & $6.24 \pm 4.12$ & $6.19 \pm 2.73$ & 0.934 & 0.01 \\
\hline
\end{tabular}

Levene's test did not show statistical differences. Therefore, the normality of the sample was assumed in all subscales, except for motivation: Stress control ( $F=0.164, p=0.686)$, influence of performance evaluation $(F=0.456, p=0.500)$, motivation $(F=7.557, p=-0.007)$, mental ability $(F=3.381, p=0.068)$, and team cohesion $(F=0.033, p=0.866)$.

The data in Table 2 show higher values for motivation, mental ability, and team cohesion for female professional soccer players, although only motivation showed statistically significant differences. Moreover, female amateur soccer players exhibited higher values for stress control, and the influence of performance evaluation, with statistically related differences. The effect size (d) of the significant variables, stress control, influence of performance evaluation, and motivation, was medium or medium-low; therefore, these data must be taken with caution. 
The results obtained from the discriminant analysis (Table 3) to determine the differences in the psychological profile of both groups demonstrated that the discriminant function was significant $(p=0.001)$ and correctly classified in $69.4 \%$ of the cases.

Table 3. Standardized coefficients of the discriminant analysis between professional and amateur players.

\begin{tabular}{cc}
\hline Psychological Factors & Standardized Coefficients \\
\hline Stress control & $0.637^{*}$ \\
Influence of performance evaluation & $0.399^{*}$ \\
Motivation & $-0.432^{*}$ \\
Mental skills & $-0.307^{*}$ \\
Team cohesion & -0.017 \\
\hline
\end{tabular}

* SC discriminant value $\geq 0.30$.

\section{Discussion}

The aim of this study was to analyses the psychological characteristics of professional female soccer players and amateur soccer players, as well as to determine the existing differences in the psychological profile of both groups. The results indicate that female professional soccer players present higher values for motivation, mental ability, and team cohesion, although only statistically significant differences in motivation were observed. On the other hand, the female amateur soccer players presented higher values for stress control and the influence of performance evaluation showed statistically significant differences.

As indicated, the female professional players displayed higher scores for motivation compared to the female amateur players. This subscale assesses the basic motivation for the sport practiced and the daily motivation related to the usual practices of their sport (training, lifestyle, travel, study-sport combination, etc.). Our results corroborate Pestillo de Oliveira et al.'s [16] study on male soccer players. In fact, being a professional may determine that players have a greater involvement with their sports practice and they live as if sports were very important for them. However, it is different in female amateur players, perhaps because they live in a more relaxing way than professionals. In addition, gender stereotypes may be affecting female motivation by pushing women to do something to demonstrate that they may do it as well as men do. In fact, females face stereotypes that have been generated for many years and face more pressure from society to play "male sports" than men [37].

However, the scores obtained in this study by female professional soccer players in the two factors of stress control and the influence of performance evaluation are lower than those obtained by amateur players. Amateur players may manage stress better than professionals because they are less affected by potentially stressful threats, and they manage the impact better due to the evaluation made by themselves or others of their performance. In this sense, in the study by Arias, Cardoso, Aguirre, and Arenas [19], male footballers showed superior scores for the influence of performance evaluation; that is, they better managed the impact of the evaluation. The greater responsibility perceived by the professional players with respect to their competency may be affecting the greater difficulties they face in stress management. In this sense, it is important to consider that soccer has historically been a sport practiced by men, with a very important masculine ideology burden [38,39], and the recent incorporation of women into it may have caused a sense of responsibility for what might be affecting their perception of stress. The perception of stress in sports practice, whether in training sessions or competitions, seems to be lived differently by males and females, and within females, differently by professionals and amateurs. In fact, it seems that the affected females perceive stressful situations as less controllable [40,41]. Therefore, it is possible that professional players will have a greater demand when evaluating their own performance and a greater sensitivity to the evaluations that others make about their performance.

Empirical evidence has shown that stress is a variable that can affect not only sports performance, but also other aspects, such as health (physical and psychological), well-being, and satisfaction with 
sports practice $[42,43]$. In this sense, the findings of this study have pointed out that, although the learning of psychological techniques and strategies may be fundamental for both professional and amateur players, it is much more necessary for professionals. These results are consistent with different studies on the role of psychological training programs [43,44].

Finally, the scores obtained in other subscales, such as team cohesion and mental ability, are higher in professional players, although these differences are not significant. It is possible that female professional players show a greater tendency to work in groups and strengthen the team by dedicating more hours and spending more time together in an effort to achieve a common goal $[45,46]$. This tendency is very important from the point of view of sports cohesion and cooperation, and its importance in performance and perceived subjective well-being is high [47,48]. As Basevitch [49] indicates, the psychological skills required to make optimal decisions and perform consistently in elite soccer include individual and team components that determine the interest in variables that influence team cohesion. In addition, one of the positive aspects involved from the perspective of team building is team cohesion, which can also be related to the perception of individual performance. According to Olmedilla et al. [27], who carried out a study on sub-16 and sub-18 soccer players, team cohesion is negatively related to the player's perception of performance. It may be that individual exposure to performance evaluation is experienced with a high stress load, and "refuge is sought" in the cohesion of the sports team. Otherwise, it is also possible that female professional players have more psychological resources to face sports practice than amateurs. It seems necessary to improve the use of techniques and strategies that increase their psychological skills and abilities, and thus are able to adequately manage stress and the impact of evaluations of their performance [50-53]. In addition, gender seems relevant when addressing psychological training [54], given that both the repertoire of psychological skills (relaxation, negative thinking in competitions, internal dialogue during competitions, and visualization) and interest in this type of work are not equal for females and males. Moreover, these results are of great importance for the coach's work, since it can help them establish tasks and training methods that are more in line with the characteristics of their players, whether professional or amateur [55-57].

These findings should be treated with caution due to a number of limitations. First, this investigation includes a convenient sample, and studies should be carried out on a larger population. Secondly, the study design is cross-sectional, so the absence of repeated measures must be taken into account. Longitudinal studies that corroborate these findings are required. Finally, this study has not taken into account the age variable. Although there is no consensus on the influence of the age variable on certain psychological characteristics, future research is necessary.

\section{Conclusions}

The main conclusions of the present study, with the sample referred, are as follows:

- Female professional soccer players show a higher level of motivation than female amateur soccer players, in terms of both basic motivation for practicing sports and daily motivation related to the usual practices of their sport.

- Female amateur soccer players show better stress management and better management of the impact of performance evaluation than female professional soccer players.

Author Contributions: Conceptualization, C.R.-E. and A.O.; methodology, A.O. and I.M.; software, I.M.; formal analysis, A.O. and I.M.; investigation, C.R.-E. and A.O.; resources, C.R.-E.; data curation, C.R.-E.; Writing-Original draft preparation, J.J.T.; Writing-Review and editing, C.R.-E., A.O. and I.M.; visualization, A.O. and I.M.; supervision, C.R.-E. and I.M.; project administration, J.J.T. All authors have read and agreed to the published version of the manuscript.

Funding: This research received no external funding.

Acknowledgments: This research was partially funded by the Football Federation of the Region of Murcia. Project number: Grant FFRM-UMU-040092 321B 6450214704. 
Conflicts of Interest: The authors declare no conflict of interest.

\section{References}

1. Dohme, L.C.; Piggott, D.; Backhouse, S.; Morgan, G. Psychological skills and characteristics facilitative of youth athletes' development: A systematic review. Sport Psychol. 2019, 33, 261-275. [CrossRef]

2. Hernández-Mendo, A. Un cuestionario para la evaluación psicológica de la ejecución deportiva: Estudio complementario entre TCT y TRI. Rev. Psicol. Deporte 2006, 15, 71-93.

3. Reche García, C.; Cepero-González, M.; Rojas-Ruiz, F.J. Perfil psicológico en esgrimistas de alto rendimiento. Cult. Cienc. Deporte 2012, 7, 35-44.

4. López-Gullón, J.M.; Torres-Bonete, M.D.; Berengüi, R.; Díaz, A.; Martínez-Moreno, A.; Morales-Baños, V.; García-Pallarés, J. Rendimiento físico y psicológico en lucha olímpica: Predictores del éxito en lucha femenina. An. Psicol. 2012, 28, 215-222.

5. Reigal Garrido, R.E.; Delgado Giralt, J.; López Cazorla, R.; Hernández Mendo, A. Perfil psicológico deportivo y ansiedad estado competitiva en triatletas. Rev. Psicol. Deporte 2018, 27, 0125-0132.

6. Anderson, R.; Hanrahan, S.J.; Mallett, C.J. Investigating the optimal psychological state for peak performance in Australian elite athletes. J. Appl. Sport Psychol. 2014, 26, 318-333. [CrossRef]

7. Arthur, R.A.; Fitzwater, J.; Roberts, R.; Hardy, J.; Arthur, C.A. Psychological skills and "the paras": The indirect effects of psychological skills on endurance. J. Appl. Sport Psychol. 2017, 29, 449-465. [CrossRef]

8. Hernández-Mendo, A.; Morales-Sánchez, V.; Peñalver, I. Replicación de las propiedades psicométricas del Inventario Psicológico de Ejecución Deportiva. Rev. Psicol. Deporte 2014, 23, 311-324.

9. López-Gullón, J.M.; García-Pallarés, J.; Berengüi Gil, R.; Martínez-Moreno, A.; Morales Baños, V.; Torres-Bonete, M.D.; Díaz, A. Factores físicos y psicológicos predictores del éxito en lucha olímpica. Rev. Psicol. Deporte 2011, 20, 0573-0588.

10. Urra, B. Evaluación de la efectividad del entrenamiento de estrategias de afrontamiento en el nivel de ansiedad precompetitiva en tenimesistas. Rev. Psicol. Deporte 2014, 23, 67-74.

11. Dias, C.; Cruz, J.F.; Fonseca, A.M. Ansiedad, percepción de amenaza y estrategias de afrontamiento en el deporte: Diferencias individuales en el rasgo de ansiedad. Ansiedad Estrés 2011, 17, 1-13.

12. Gledhill, A.; Harwood, C.; Forsdyke, D. Psychosocial factors associated with talent development in football: A systematic review. Psychol. Sport Exerc. 2017, 31, 93-112. [CrossRef]

13. Riddick, C.C. Comparative psychological profiles of three groups of female collegians: Competitive swimmers, recreational swimmers, and inactive swimmers. J. Sport Behav. 1984, 7, 160.

14. Saber, M.; Talebi, R.; Hemayattalab, R.; Arabameri, E. Comparison of selected metal skills between elite and non-elite male and female taekwondo athletes. WJSS 2012, 6, 32-38.

15. Vaca, M.R.; Egas Romo, S.R.; García Quiñonez, O.F.; Feriz Otaño, L.; Rodríguez Torres, Á.F. Pre-competitive anxiety in high-performance, amateur and novice karate. Rev. Cuba. Invest. Biomed. 2017, 36, $239-247$.

16. Pestillo de Oliveira, L.; Andrade do Nascimento Junior, J.R.; Nickenig-Vissoci, J.R.; Ferreira, L.; Norraila da Silva, P.; Lopes-Vieira, J.L. Motivación autodeterminada y estrategias de afrontamiento en futbolistas: Un estudio con jugadores en diferentes fases de desarrollo deportivo. Rev. Psicol. Deporte 2016, 25, 261-269.

17. Byon, K.K.; Carroll, M.S.; Cottingham, M.; Grady, J.; Allen, J.T. Examining gender differences in the effect of spectator motivation on sport consumption behaviours at collegiate wheelchair basketball games. JVEM 2011, 3, 11-28.

18. Junge, A.; Feddermann-Demont, N. Prevalence of depression and anxiety in top-level male and female football players. BMJ Open 2016, 2, e000087. [CrossRef]

19. Arias, I.; Cardoso, T.; Aguirre, H.; Arenas, J. Características psicológicas de rendimiento deportivo en deportes de conjunto. Psicogente 2016, 19, 25-36.

20. Cabrita, T.; Rosado, A.; Marcos, V.; Serpa, S. Relaciones entre identidad atlética y personalidad en el deporte de competición. Rev. Psicol. Deporte 2014, 23, 247-253.

21. Jaakkola, T.; Wang, C.J.; Soini, M.; Liukkonen, J. Students' perceptions of motivational climate and enjoyment in Finnish physical education: A latent profile analysis. J. Sport Sci. Med. 2015, 14, 477.

22. Alonso, D.A.; Marcos, F.M.L.; Oliva, D.S.; Ponce, I.G.; Chamorro, J.M.L. ¿Es compatible el deporte en edad escolar con otros roles sociales?: Un estudio a través de la Teoría de la Autodeterminación. Retos Nuevas Tend. Educ. Fís. Deporte Recreac. 2012, 21, 50-52. 
23. Álvarez, O.; Estevan, I.; Falcó, C.; Hernández-Mendo, A.; Castillo, I. Perfil de habilidades psicológicas en taekwondistas universitarios y su relación con el éxito en competición. Cuad. Psicol. Deporte 2014, 14, 13-20. [CrossRef]

24. Williams, K.T. Physiological and Psychological Characteristics of First Division Female Football Players. Ph.D. Thesis, University of Johannesburg, Johannesburg, South Africa, 2017.

25. Arroyo del Bosque, R.; Irazusta Adarraga, S.; González Rodríguez, Ó. Impacto del Resultado Post-Partido en el Estado de Ánimo en Jóvenes Jugadoras de Fútbol. Ph.D. Thesis, Universidad del País Vasco, País Vasco, Spain, 2016.

26. Kristjánsdóttir, H.; Jóhannsdóttir, K.R.; Pic, M.; Saavedra, J.M. Psychological characteristics in women football players: Skills, mental toughness, and anxiety. Scand. J. Psychol. 2019, 60, 609-615. [CrossRef]

27. Olmedilla, A.; Ruiz-Barquín, R.; Ponseti, F.J.; Robles-Palazón, F.J.; García-Mas, A. Competitive psychological disposition and perception of performance in young female soccer players. Front. Psychol. 2019, 10, 1168. [CrossRef] [PubMed]

28. Olmedilla, A.; García-Mas, A.; Ortega, E. Características psicológicas para el rendimiento deportivo en jóvenes jugadores de fútbol, rugby y baloncesto. Acción Psicol. 2017, 14, 7-16. [CrossRef]

29. Rutkowska, K.; Bergier, J. Psychological gender and emotional intelligence in youth female soccer players. J. Hum. Kinet. 2015, 47, 285-291. [CrossRef]

30. Gimeno, F.; Buceta, J.M.; Pérez-Llantada, M. El cuestionario “Características psicológicas relacionadas con el rendimiento deportivo" (CPRD): Características psicométricas. Anal. Psicol. 2001, 1, 93-133. [CrossRef]

31. Mahoney, M.J.; Gabriel, T.J.; Perkins, T.S. Psychological skills and exceptional athletic performance. TSP 1987, 1, 181-199. [CrossRef]

32. Gimeno, F.Y.; Pérez-Llanta, M.C. Características psicométricas del cuestionario CPRD. In Evaluación Psicológica en el Deporte: El Cuestionario CPRD [Psychological Assessment in Sport: The CPRD Questionnaire]; Gimeno, F., Buceta, Y.J.M., Eds.; Dykinson: Madrid, Spain, 2010; pp. 81-124.

33. Ntoumanis, N. A Step-By-Step Guide to SPSS for Sport and Exercise Studies: A Step-By-Step Guide for Students; Routledge: London, UK, 2003.

34. Tabachnick, B.G.; Fidell, L.S. Using Multivariate Statistics, 3rd ed.; Harper Collins: New York, NY, USA, 2001.

35. Batterham, A.M.; Cox, A.J. Spreadsheets for analysis of controlled trials, with adjustment for a subject characteristic. J. Sports Sci. 2006, 10, 46-51.

36. Hopkins, W.G. A spreadsheet to compare means of two groups. Sportscience 2007, 11, 22-24.

37. Torrebadella-Flix, X. Fútbol en femenino. Notas para la construcción de una historia social del deporte femenino en España, 1900-1936. Investig. Fem. 2016, 7, 313-334. [CrossRef]

38. Hargreaves, J. Promesa y problemas en el ocio y los deportes femeninos. In Materiales de Sociología del Deporte; Barbero, J.I. La Piqueta: Madrid, Spain, 1993; pp. 109-132.

39. Uría, J. Imágenes de la masculinidad. El futbol español en los años veinte. Ayer 2008, 72, 121-155.

40. González, J.; Sandoval, J.M. Estrategias de afrontamiento y personalidad en la adaptación de jóvenes a su práctica deportiva. Diferencias de género. SPORT TK 2015, 4, 57-62. [CrossRef]

41. Hampel, P.; Petermann, F. Age and Gender Effects on Coping in Children and Adolescents. J. Youth Adolesc. 2005, 34, 73-83. [CrossRef]

42. Carolina-Paludo, A.; Nunes-Rabelo, F.; Maciel-Batista, M.; Rúbila-Maciel, I.; Peikriszwili-Tartaruga, M.; Simões, A.C. Game location effect on pre-competition cortisol concentration and anxiety state: A case study in a futsal team. Rev. Psicol. Deporte 2020, 29, 105-112.

43. Olmedilla, A.; Ortega, E.; Robles-Palazón, F.J.; Salom, M.; García-Mas, A. Healthy practice of female soccer and futsal: Identifying sources of stress, anxiety and depression. Sustainability 2018, 10, 2268. [CrossRef]

44. Olmedilla, A.; Sánchez-Aldeguer, M.F.; Almansa, C.M.; Gómez-Espejo, V.; Ortega, E. Entrenamiento psicológico y mejora de aspectos psicológicos relevantes para el rendimiento deportivo en jugadoras de fútbol. Rev. Psicol. Apl. Deporte Ejerc. Fis. 2018, 3, 1-11. [CrossRef]

45. Duguay, A.M.; Loughead, T.M.; Cook, J.M. Athlete Leadership as a Shared Process: Using a Social-Network Approach to Examine Athlete Leadership in Competitive Female Youth Soccer Teams. TSP 2019, 33, 189-202. [CrossRef]

46. Leo, F.M.; González-Ponce, I.; García-Calvo, T.; Sánchez-Oliva, D. The relationship among cohesion, transactive memory systems, and collective efficacy in professional soccer teams: A multilevel structural equation analysis. Group Dyn. Theory Res. Pract. 2019, 23, 44. [CrossRef] 
47. Borrego, C.C.; Cid, L.; Silva, C. Relationship between group cohesion and anxiety in soccer. J. Hum. Kinet. 2012, 34, 119-127. [CrossRef]

48. Lowther, J.; Lane, A. Relationships between mood, cohesion and satisfaction with performance among soccer players. Athl. Insight 2002, 4, 57-69.

49. Basevitch, I. Psychological Demands of Soccer: A Decision-Making Perspective. In Elite Soccer Players; Routledge: London, UK, 2019; pp. 19-34.

50. Aoyagi, M.W.; Poczwardowski, A.; Statler, T.; Shapiro, J.L.; Cohen, A.B. The performance interview guide: Recommendations for initial consultations in sport and performance psychology. Prof. Psychol. Res. Pract. 2017, 48, 352-360. [CrossRef]

51. Brown, D.J.; Fletcher, D. Effects of psychological and psychosocial interventions on sport performance: A meta-analysis. Sports Med. 2017, 47, 77-99. [CrossRef]

52. McCormick, A.; Meijen, C.; Anstiss, P.A.; Jones, H.S. Self-regulation in endurance sports: Theory, research and practice. Int. Rev. Sport Exerc. Psychol. 2017, 12, 235-264. [CrossRef]

53. Moreno-Fernández, I.M.; Gómez-Espejo, V.; Olmedilla-Caballero, B.; Ramos, L.M.; Ortega, E.; Olmedilla, A. Eficacia de un programa de preparación psicológica en jugadores jóvenes de fútbol. Rev. Psicol. Apl. Deporte Ejerc. Fis. 2019, 4, e14. [CrossRef]

54. Einarsson, E.I.; KristjánsdÓttir, H.; Saavedra, J.M. Relationship between elite athletes' psychological skills and their training in those skills. Nord. Psychol. 2020, 72, 23-32. [CrossRef]

55. García-Calvo, T.; González-Ponce, I.; Ponce, J.C.; Tomé-Lourido, D.; Vales-Vázquez, Á. Incidencia del sistema de puntuación de las tareas sobre la carga mental del entrenamiento en fútbol. Rev. Psicol. Deporte 2019, 28, 79-86.

56. Ibáñez, S.J.; Pérez-Goye, E.; García-Rubio, J.; Courel-Ibáñez, J. Effects of task constraints on training workload in elite women's soccer. Int. J. Sports Sci. Coach. 2020, 15, 99-107. [CrossRef]

57. Merino, A.; Arraiz, A.; Sabirón, F. La construcción de la identidad competitiva del niño que práctica fútbol prebenjamín. Rev. Psicol. Deporte 2019, 28, 281-289.

(C) 2020 by the authors. Licensee MDPI, Basel, Switzerland. This article is an open access article distributed under the terms and conditions of the Creative Commons Attribution (CC BY) license (http://creativecommons.org/licenses/by/4.0/). 